UDC 378.4

DOI: https://doi.org/10.30839/2072-7941.2018.149679

\title{
UNIVERSITY COLLABORATION WITH BUSINESS IN CURRICULUM DEVELOPMENT
}

\author{
(C) MEJERYTÉ-NARKEVIČIENĖ, KRISTINA \\ Lithuanian Sports University (Kaunas, Lithuania) \\ E-mail: kristina.mejeryte @1su.lt, ORCID 0000-0003-0629-3265
}

\begin{abstract}
The relevance of the research is that university and business collaboration is the main implementation tool of the third university mission. University-business collaboration (UBC) has risen to one of the top priorities for many higher education institutions, with its importance mirroring attention from scholars and policy makers worldwide. In the face of increasing global competition, business was challenged to seek new methods for creating their competitive advantage and at the same time, the decreasing budgets of higher education institutions were pressured to find new streams of financing. In both cases, collaboration in different forms is an important method for achieving their objectives. Ten types of UBC are related quite directly to the missions of the university and the needs of business but one of them curriculum development and delivery is very important. Using this form for UBC, could help to develop human resources relevant to modern society. The main instruments and activities in this form of collaboration as identified by business is too little used. The research aim was to identify the activities of university and leisure organizations used for collaboration in curriculum development. The objectives of the research: to determine the forms of UBC, to identify the activities used for universities and leisure organizations collaboration in curriculum development. Analysis of recent research and publications. UBC became the subject of education and management sciences. Recently, much attention has been paid to UBC collaboration practices (M. Ilyas, G. Dutrenit, D. Golder-Buckley, V. Garousi, K. Petersen) especially a lot of research on practices was done about universities collaboration in R\&D and commercialisation of R\&D. P. D'Este and M. Perkmann explored the factors of UBC, the types were identified by T. Davey, T. Baaken, V. Galan Muros, A. Meerman, T. Barnes, A. Gibbons and the levels of UBC were represented by B.N. Ponomariov, P.C. Boardman, T. Davey. The benefits of UBC to research quality have been studied by researchers $\mathrm{M}$. Crespo and H. Dridi, as a collaborative factor for learning improvement by researchers K. Ramakrishnan, N.M. Yasin, A. Draghici, as a quality factor UBC was analysed by M. Perkmann, Z. King, S. Pavelin. The main researchers who analysed the UBC in curriculum development was the T. Davey, A. Healy, C. Plewa, T. Baaken. An overview of the study of this object shows that it was mostly analysed in vocational training and in last ten years' period the publications is growing in UBC. Research methodology. The paper seeks to represent the collaboration forms, which was used by university with the business organizations from leisure industry. As well, it seeks to identify the activities of business collaboration in curriculum design, development and evaluation. Methods applied for the research was scientific literature review, a questionnaire survey for business organization leaders and mathematical statistics.

Conclusion. The results of business organizations show the positive impact for increasing the university collaboration as a hole but in study programs, curriculum development shows that it is needed more business engagement. With the business engagement into curriculum academics, expect to be given the opportunity to transfer theoretical ideas into practical projects and to implement research in the real world. At the same time, the business engage in the curriculum development mostly through giving guest's lectures and consultations, place for practice, or organizing the different events with the academics.
\end{abstract}


Keywords: university and business collaboration, collaboration forms, curriculum design, curriculum development, business collaboration in curriculum.

Analysis of recent research and publications.

The high unemployment rate in Europe [8], as well as declining employment rates [1] and the need to develop entrepreneurship in order to progress, are increasingly emphasizing the importance of collaboration between the university and business. In the political and scientific area, UBC is increasingly becoming the subject of heated debate. An overview of scientific literature has shown that universities should not only traditionally teach and carry out research, but they has to implement the "third" mission aimed at intensifying collaboration between science and business [12, 13, 23]. For a long time, entrepreneurship, the provision of commercial services, and cooperation with business enterprises have not been linked to the academic world. The universities, business and governments now are interested in good and effective collaboration which would be beneficial for all sides.

Universities of today have to find the appropriate balance between teaching, basic and applied research, and entrepreneurship. Recently, much attention has been paid to UBC collaboration and a lot of knowledge transfer between universities and business was conducted through various channels and practices $[6,14$, 10, 17]. The biggest impact for the further development of UBC was made in 2011 by scientists T. Davey et al. By funding the project "University Business Cooperation in
Europe" the UBC was analysed in all Europe countries. According to this an extensive study among European universities [4] and other studies [5, 24, 28], there are ten types of UBC, which are related quite directly to the missions of the university (Education, Research and Entrepreneurship) and the needs of business (Entrepreneurs, Qualified employees, Innovation, Turnover and profit): Curriculum development and delivery, Lifelong learning, Student mobility, Academic mobility, Commercialization in $R \& D$, Entrepreneurship, Governance, Resource (facilities, equipment \& data), Sharing and popularization of science in the Media. Five forms of outlined collaboration are particular relevance to education collaboration, although all of them can play an important role.

The partnerships have not always been smooth sailing in all the forms of UBC. There is a cultural divide between how universities and business operate [16], think and behave [18]. As long as there is mutual benefit, an access to expert researchers with innovative capacity and a needed stream of funding for universities, the collaborations between universities and business will continue. Even if UBC is analysed in different sections, the emerging problems, which still need to solve is been addressed to the organization itself or their members.

\section{UBC collaboration} curriculum development. 
Universities collaboration with the business in curriculum development, in particular, has received very little academic attention [25], despite its widespread practice [4, 15], and its ability to enrich education [3,9]. A. Healy et al. report, presented the impact of UBC in the context of education were the curriculum design encompasses the design of university programs, courses and related content at all levels. Still this report showed that curriculum delivery is seen and understood in this context as the delivery of programs, courses and content to the students via a large range of mechanisms [4]. The lack of the research in this content is particularly surprising and especially when we still have enough research about benefits of collaboration with different mechanisms [4, 22, 26]. With growing reports of that benefits relating to business and universities co-designing and co-delivering curricular and developing practices aimed at supporting such collaborations, there was investigated the instruments driving business engagement in curriculum-related activities and achieving an alignment of business needs with universities offers [24]. Even if the collaboration of universities with the business was analysed in different levels, the emerging problems is still addressed to the university or business organization itself or their members.

The business organizations rely on universities to deliver qualified and skilled employees and universities rely on business to provide work placements for their students and to employ their graduates [24]. Now universities face strong pressures to marry theoretical understanding with real-life practice to ensure high levels of graduate employability $[11,24]$ by advancing and modernising their curricula.

For the best fit to occur between input and output (graduates), the two parties, should be clearly and regularly communicating their expectations with each other. The most successful partnerships is built on trust, having a common vision and seeing mutual benefits.

Collaboration activities in the field of education illustrate the many ways in which businesses and universities work together. UBC activities can be both direct and indirect, the reports of A. Healy et al. [15], cover 6 areas where collaboration is usually taking place. It is noteworthy that experiential learning and entrepreneurship education are included in the curriculum concept, although traditionally it may not be considered as traditional educational methods.

One of the main phase in the curriculum development is a curriculum design [15, 24], were collaboration with the business in some activities could help for universities: to design new study programs, new study subjects, determine the competencies of study programs, study plans, identify the teaching and learning methods, prepare required study material, plan the students placements etc. $[2,5,15$, 20].

The next phase in the curriculum development is a curriculum delivery. Businesses and universities also work together for the joint implementation of study content / programs. In this 
area, we can see the widest UBC range of activities. The activities range from the staff employed in the company, the delivery of lecturing and teaching materials to visiting firms, internships and work with students in projects (both individually and in groups), membership on a university advisory committee [5, 15]. Companies can also provide access to facilities and facilities that are not available at universities or to organize intensive summer schools [4, 7, 27]. For universities, of course, the core activity is the implementation of study programs.

The third possible phase of UVB in curriculum delivery is curriculum evaluation or assessment of the student's study results or the assessment of the study content [20]. This may include presenting student presentations to the management or the staff of the company involved in the study process, or the assessment of the subject/course material prepared by the business organizations, etc. [26] Co-operation is stronger if there is a general assessment [15], and he can be applied in a wide range of ways, from practice to the final thesis of students. As well in this phase it is very important that the business would be involved also not only in the internal evaluations but also in the external quality evaluations of the following study programmes in the different study fields [15, 21].

The most important thing in curricular development is that the business engaged in curriculum design, curriculum delivery and curriculum evaluation. Engaging with the universities in curricular design, delivery and evaluation not only allows business to influence the education of the future workforce but engage with prospective future employees throughout their educational experience [24]. Also, depending on the collaboration type, other reason like raising of the brand, retaining and upskilling staff or exchanging knowledge may prevail as well [15].

\section{Research methodology}

Based on a through literature review were identified universities and leisure organizations forms in curriculum development: design, delivery and evaluation. For this study purpose it was organized the quantitative research with the Lithuanian Sports university (LSU) social partners only from business leisure organizations. Quantitative research was used to gain quantify opinions of UBC forms in which they engage and activities in curriculum development. This research is based only on the opinion of business organizations leaders who are the LSU social partners.

LSU has 221 social partners but only 24 are from business organizations. All the 24 business organizations leaders participated in the survey and were asked to fulfil the survey questionnaire as the respondents for this research from March to May of 2018. 19 business organizations leaders were males and 5 females, the age of the respondents ranged from 31 to 56 .

Questionnaire was used as data collection instrument. The questionnaire was from two parts: engagement in UBC types and business engagement activities in curriculum development. In the 
second part of the questionnaire about curriculum development the activities of curriculum design, delivery and evaluation was selected from literature review and used the five point Likert-scaled ranging. The validity of questionnaire was checked by two senior and well experienced educators of Sport management, economy and sociology department and one expert of research methodology. After data collection was done the statistical analysis of collected data.

\section{Results}

In Lithuania it is used to think that the university takes first steps in collaborating with the business, but there is also another way when the business is searching the ways for the collaboration. As in all countries, there is also a possible third way to encourage UBC with the various political measures. The research results showed that the minority of business organization leaders (25\%) engage in one type of UBC, the others are already collaborating in two types $(41.6 \%)$ or tree types $(33,3 \%)$ of UBC. This confirms that there is a strong link between forms of collaboration [15]. When business engage in one form of co-operation, later they are collaborating in other similar activities or in other forms of $\mathrm{UBC}$ as well.

Collaboration between universities and businesses in various types of UBC can be at various levels, it is also taking place in different ways, depending on the type of institution involved, and the specifics of the individual areas of science. It can argued that relationships are often supported by a variety of communication mechanisms, such as research collaboration, industrial contribution to the development of study programs, student support and recruitment, and the exchange of scientific staff [19]. Figure 1 shows in witch types of UBC the respondents from business organizations are engaging.

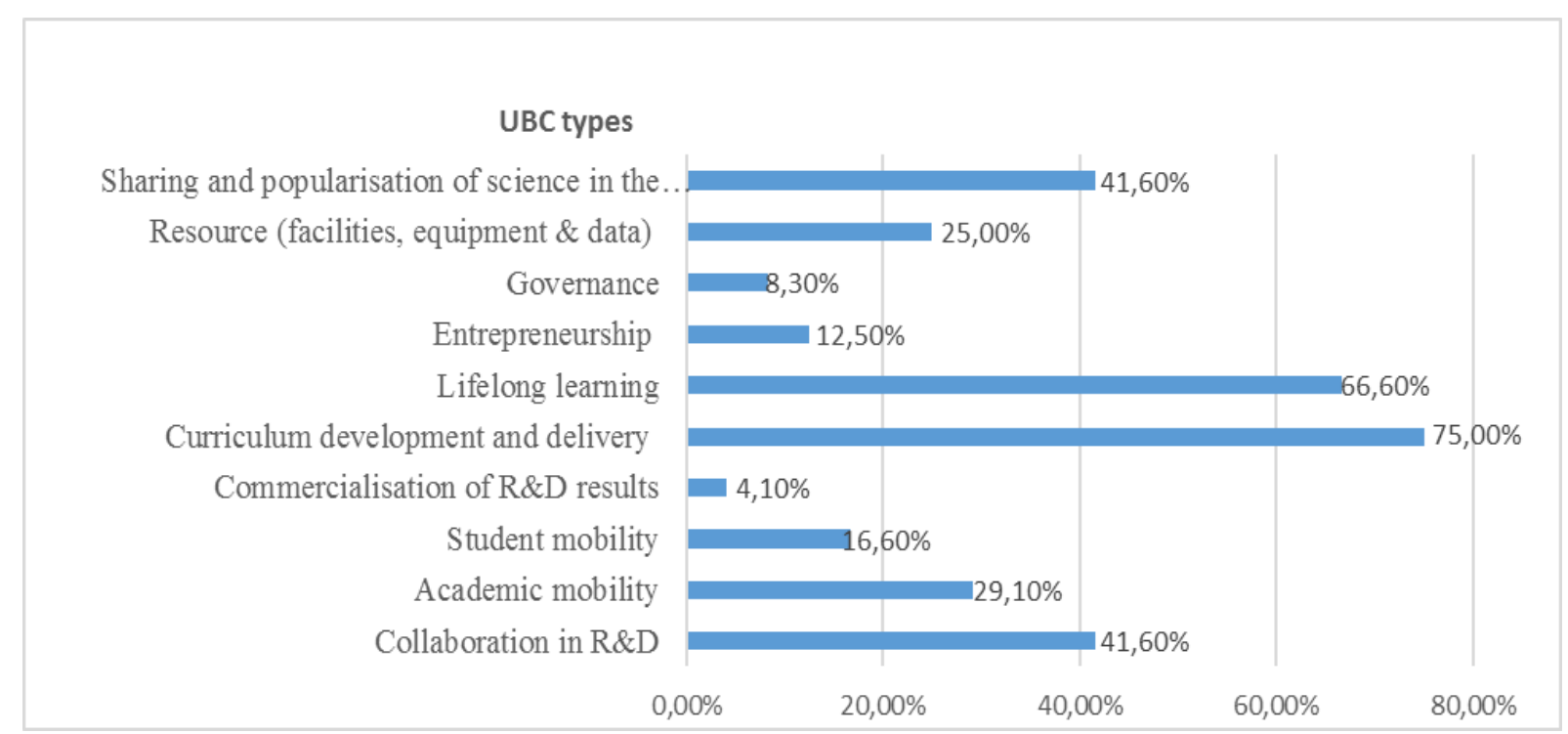

Figure 1. Percentage of business engagement by UBC types 
The quality of the curriculum development has to pass different subsequent steps that demand effective and efficient monitoring and control of each process. It is not a simple process, which could be accomplished without collaboration of stakeholders [4, 5]. Curriculum development is a complex of different activities and those activities we can divide in three parts curriculum design, delivery and evaluation. As you can see in Table 1 is representing the business activities in curriculum

The curriculum development second phase is curriculum delivery. The table 2 shows that the highest engagement of business is informal communication with the teachers and students, organising and implementing the student practice, preparation of joint seminars and conferences and implementation of joint research and projects. The lowest business organizations involvement in design. The activities were business engaging most is student placement planning, preparation of study program plan and in determination of distinctive features of the study program, further studies and possibilities of professional activity. The lowest business involvement is in identification and preparation of the teaching and learning methods in study program. It shows that the activity were business could be the leader his engagement is the lowest.

curriculum delivery is in preparation the study program subjects / modules. This means that the curriculum subjects / modules quality depends mostly on teachers. Inclusion of business in the realization or delivery of curriculum in activities in all phases of curriculum design creates possibilities for a more successful collaboration with the university [4, $15]$.

Table 1. Curriculum design activities in which business engage

\begin{tabular}{|l|c|}
\hline \multicolumn{1}{|c|}{ UBC in curriculum design activities } & $\begin{array}{c}\text { Average } \\
\text { score }\end{array}$ \\
\hline Determination of study program title, goal setting and orientation & 3,45 \\
\hline $\begin{array}{l}\text { Determination of distinctive features of the study program, } \\
\text { further studies and possibilities of professional activity }\end{array}$ & 3,66 \\
\hline Determination of the study program competencies & 2,70 \\
\hline Determination of the study program modules learning outcomes & 2,50 \\
\hline Preparation the study program subjects / modules & 2,41 \\
\hline $\begin{array}{l}\text { Identification and preparation of the teaching and learning } \\
\text { methods in study program }\end{array}$ & 1,6 \\
\hline $\begin{array}{l}\text { Preparation of study program required study material (articles, } \\
\text { textbooks, etc.) }\end{array}$ & 2,04 \\
\hline Preparation of study program plan & 3,62 \\
\hline Student placement planning & 3,87 \\
\hline Joint research, project planning & 2,29 \\
\hline Student / graduate recruitment planning & 2,83 \\
\hline Business representation as a member in study program committee & 2,16 \\
\hline
\end{tabular}


Table 2. Curriculum delivery activities in which business engage

\begin{tabular}{|l|c|}
\hline \multicolumn{1}{|c|}{ UBC in curriculum delivery activities } & $\begin{array}{c}\text { Average } \\
\text { score }\end{array}$ \\
\hline Preparation the study program subjects / modules & 2,58 \\
\hline Organising and implementing the student practice & 4,75 \\
\hline Improvement of the study program plan & 3,16 \\
\hline Adaptation of the teaching and learning methods in study program & 2,83 \\
\hline Implementation of joint research and projects & 4,50 \\
\hline Teaching students via lectures and seminars & 4,29 \\
\hline Preparation of joint seminars and conferences & 4,58 \\
\hline Informal communication with the teachers and students & 4,87 \\
\hline $\begin{array}{l}\text { Collaboration in joint activities through various associations, } \\
\text { unions, etc. }\end{array}$ & 3,75 \\
\hline Activities in career centers & 2,83 \\
\hline Financially support the acquisition of equipment & 2,50 \\
\hline Financially support students through scholarships & 3,08 \\
\hline Financially support students through partial financing of studies & 2,04 \\
\hline Students / graduates recruitment in organizations & 3,37 \\
\hline Informal student counselling, writing postgraduate work in practice & 4,66 \\
\hline Formal student counselling when writing final theses & 3,41 \\
\hline Proposals for graduation theses for students & 3,16 \\
\hline Recommendations on the implementation of the study program & 4,00 \\
\hline
\end{tabular}

Curriculum evaluation should be taken to ensure the quality of curriculum to produce graduates equipment with skills and knowledge that prepare them to succeed in a knowledge-based society [15, 24]. Basically, the research results of business involvement in this phase is the lowest. As the result showed in the table 3 most of activities are scored very low. The highest engagement of business is seen only in evaluation of the student practice organization and students' assessment of practical work. The lowest is involvement is in external quality evaluations of the study programs (as a part of commission), evaluation of study program subjects / modules, Preparing the documents for external quality evaluations of study programs and etc.

Table 3. Curriculum evaluation activities in which business engage

\begin{tabular}{|l|c|}
\hline \multicolumn{1}{|c|}{ UBC in curriculum evaluation activities } & $\begin{array}{c}\text { Average } \\
\text { score }\end{array}$ \\
\hline $\begin{array}{l}\text { Providing the recommendations of the organisation of the evaluation } \\
\text { of the study program }\end{array}$ & 2,54 \\
\hline $\begin{array}{l}\text { Evaluation of the student practice organization and students' } \\
\text { assessment of practical work }\end{array}$ & 4,66 \\
\hline Student assessment in final work commissions & 2,79 \\
\hline Evaluation of study program subjects / modules & 183 \\
\hline
\end{tabular}

University collaboration with business in curriculum development 


\begin{tabular}{|l|c|}
\hline Assessment of the suitability of the study material & 1,75 \\
\hline $\begin{array}{l}\text { Preparing the documents for external quality evaluations of study } \\
\text { programs }\end{array}$ & 2,25 \\
\hline $\begin{array}{l}\text { Engaging in external quality evaluations of the study programs (as a } \\
\text { part of commission) }\end{array}$ & 1,45 \\
\hline Recommendations for the quality of the study programs & 3,08 \\
\hline
\end{tabular}

Basically, the research results showed that business still need to extend the UBC types in there organizations and engage in more activities which are very important for curriculum development. It is seen that business is engaged only in couple of activities in different pats of curriculum development, so they don't use all instruments and methods they could or have to get better quality of graduates.

\section{Conclusion}

There is a clear relationship among the collaboration types. When a business organization leader engages in one type of collaboration, it is likely that they also undertake a similar extent of the other types of collaboration. UBC may take various forms that was influenced by different factors but even if all stakeholders seeks the main purpose of this process. It was found, that one third of business organization leaders in university collaborates in three types of UBC at the same time. The main types was curriculum development and delivery and lifelong learning, so to spread the types we should lead to the creation and develop of networks between people in university and in the business organization.

Business in curriculum design, delivery and evaluation can take on various roles, from contributions made through formal instruments to institution priorities, assessment systems, design/delivery principles or informal tools, engagement activities that are often based on personal relationships. Even if the business organizations showed the positive impact for increasing the university collaboration as a hole all collaboration types as well and curriculum development need more or less financing, motivation and also capabilities of researchers, university, and business. The curriculum development shows that it is needed more business engagement in various activities, not only in couple of them. However, the most commonly established collaboration activities were joint activities through various associations, unions, joint conferences, seminars, students practice and lectures for students.

\section{REFERENCE}

1. Asderaki, F. (2009). The Impact of the Bologna Process on the Development of the Greek Quality Assurance System. Quality in Higher Education, 15 (2), 105-122. doi: https://doi.org/10.1080/13538320902995758

2. Barnett, M. (2002). University-industry relationships in dentistry: past, present, future. Journal of Dental Education, 66 (10), 1163-1168. 
3. Carayol, N. (2003). Objectives, agreements and matching in science-industry collaborations: reassembling the pieces of the puzzle. Research Policy, 32 (6), 887-908. doi: https://doi.org/10.1016/s0048-7333(02)00108-7

4. Davey, T., Baaken, T., Galan-Muros, V. (2011). The State of European UniversityBusiness Cooperation: Part of the DG Education and Culture Study on the Cooperation between Higher Education Institutions and Public and Private Organisations in Europe, 141. 5. Davey, T. (2017). Converting university knowledge into value: how conceptual frameworks contribute to the understanding of the third mission role of European universities. International Journal of Technology Transfer and Commercialisation, 15 (1), 65. doi: https://doi.org/10.1504/ijttc.2017.10005380

6. Dutrénit, G., De Fuentes, C., Torres, A. (2010). Channels of interaction between public research organisations and industry and their benefits: evidence from Mexico. Science and Public Policy, 37 (7), 513-526. doi: https://doi.org/10.3152/030234210x512025

7. Echeverri, P., Skålén, P. (2011). Co-creation and co-destruction: A practice-theory based study of interactive value formation. Marketing Theory, 11 (3), 351-373. doi: https://doi.org/10.1177/1470593111408181

8. Eurostat (2015). Eurostat databases. Available at: https://ec.europa.eu/eurostat/

9. Forsyth, H., Laxton, R., Moran, C., van der werf, J., Banks, R., Taylor, R. (2008). Postgraduate coursework in Australia: issues emerging from university and industry collaboration. Higher Education, 57 (5), 641-655. doi: https://doi.org/10.1007/s10734-0089167-8

10.Garousi, V., Petersen, K., Ozkan, B. (2016). Challenges and best practices in industryacademia collaborations in software engineering: A systematic literature review. Information and Software Technology, 79, 106-127. doi: https://doi.org/10.1016/j.infsof.2016.07.006

11.Gillis, M., McNally, M. (2010). The influence of industry on dental education. Journal of Dental Education, 74 (10), 1095-1105.

12.Giuliani, E., Arza, V. (2009). What drives the formation of "valuable" universityindustry linkages? Research Policy, 38 (6), 906-921. doi: https://doi.org/10.1016/j.respol.2009.02.006

13.Golubavičiūtè, R., Guzavičius, A. (2009). Universitetas kaip socialiai atsakinga organizacija. Economics \& Management, 246-250.

14.Buckley-Golder, D., Way, D., Glover, M. et. al. (2015). Best Practice Strategies for Successful Innovation through University-Business Collaboration. Research Councils UK, 20.

15.Healy, A., Perkmann, M., Goddard, J., Kempton, L. (2014). Measuring the impact of university-business cooperation. Catalogue No. NC-02-14-1337-EN-N. Luxembourg: Publications Office of the European Union.Huang, M.H.

16.Ho, M. H.-C., Liu, J. S., Kuan, M. C.-H. (2016). Torn between Academic Publications and University-Industry Collaboration. Research Evaluation, 25 (2), 151-160. doi: https://doi.org/10.1093/reseval/rvw001

17.Ilyas, M. (2004). Best practices in industry-university collaboration. Government, industry and university relationships and collaboration. Published in the proceedings for the Second LACCEI International Latin American and Caribbean Conference for Engineering and Technology (LACCEI'2004), Paper No. 037.

18.Lamichhane, S., Sharma, T. N. (2013). University - Industry Relations: A Thrust for Transformation of Knowledge and Economic Acceleration. Journal of Education and Research, 2. doi: https://doi.org/10.3126/jer.v2i0.7624

19.Lam, A. (2007). Knowledge Networks and Careers: Academic Scientists in Industry University Links. Journal of Management Studies, 44 (6), 993-1016. doi: https://doi.org/10.1111/j.1467-6486.2007.00696.x

20.Laužackas, R. (2005). Profesinio rengimo metodologiya. Kaunas: Vytauto Didžiojo universiteto leidykla. 
21.Muda, N., Din, U. K. S., Majid, N., Ahmad, R. R., Shahabudin, F. A. A., Rambely, A. S., Suradi, N. R. M. (2012). Industrial Training as a Benchmark of the Employability for the Mathematical Sciences Students of UKM. Procedia - Social and Behavioral Sciences, 59, 598-603. doi: https://doi.org/10.1016/j.sbspro.2012.09.319

22.Othman, R., Omar, A. F. (2012). University and industry collaboration: towards a successful and sustainable partnership. Procedia - Social and Behavioral Sciences, 31, 575579. doi: https://doi.org/10.1016/j.sbspro.2011.12.106

23.Stokaitè, V., Pitrènaitė-Žilenienè, B. (2014). Kolektyvinio intelekto svarba igyvendinant universitetų "trečiają misiją." Social Technologies, 4 (2), 361-369. doi: https://doi.org/10.13165/st-14-4-2-09

24.Plewa, C., Galán-Muros, V., Davey, T. (2014). Engaging business in curriculum design and delivery: a higher education institution perspective. Higher Education, 70 (1), 3553. doi: https://doi.org/10.1007/s10734-014-9822-1

25.Siegel, D. J. (2007). Building a pipeline for diversity through intersectoral collaboration. Higher Education, 55 (5), 519-535. doi: https://doi.org/10.1007/s10734-0079072-6

26.Stonkienè, M., Matkevičienè, R. (2014). Trečiosios universitetų misijos poveikis mokslo žinių sklaidai universitetinèse studijose. Societal Studies, 6 (3), 611-632. doi: https://doi.org/10.13165/sms-14-6-3-10

27.Vargo, S. L., Lusch, R. F. (2004). Evolving to a New Dominant Logic for Marketing. Journal of Marketing, 68 (1), 1-17. doi: https://doi.org/10.1509/jmkg.68.1.1.24036

28.Wakkee, I. A. M., Van der Sijde, P., Nuijens, N. (2013). Valorisatie in Nederland:exploratieve verkenning van het landschap van valorisatieprogramma's'. Amsterdam: VU/FSW-Org (internal report).

МЕЙЕРІТЕ-НАРКЕВІЧЕНЕ, КРІСТІНА - викладач кафедри менеджменту, спорту, економіки і соціології, Литовський університет спорту (Каунас, Литва)

E-mail: kristina.mejeryte@1su.lt, ORCID 0000-0003-0629-3265

\section{СПІВРОБІТНИЦТВО УНІВЕРСИТЕТУ ЗІ СТУДІЕЮ БІЗНЕСУ І РОЗВИТКУ}

Анотація. Актуальність вивчення відображає той факт, що співробітництво між університетом і бізнесом розглядається як важливий спосіб реалізцаії третьої місії університету. Університети покликані шукати нові можливості для фінансування, скорочення державного фінансування і підтримки зі сторони структурних фондів, а також швидкого зростання ділової конкуренції, компанії покликані шукати нові методи для підтримки конкурентних переваг. В обох випадках різні форми співробітництва $\epsilon$ важливим способом досягення своїх цілей. Десять типів UBC напряму пов'язані 3 місіями університетів і бізнес-потребами, проте один з них є достатньо важливим покращенння змісту дослідження, що аналізується за допомогою розробки, упровадження та оцінки змісту дослідження. Така форма співробітництва між університетом і бізнесом може допомогти у розвитку людських ресурсів, пов'язаних 3 розвитком сучасного суспільства. Проте участь бізнесу в ній обмежена, діяльність щодо залучення уваги також досить обмежена i не використовується. Мета дослідження - визначити форми діяльності, у якій приймають участь представники бізнесу з метою покращення змісту навчального процесу. Завдання дослідження: визначити форми співробітництва між університетом, діловими колами та представниками бізнесу у сфері проектування, упровадження та оцінки змісту дослідження. Аналіз останніх досліджень та публікацій. 3 утворенням третьої університетської місії співробітництво між університетами і бізнесом широко аналізувалася не тільки у сфері управління, але й у сфері природничо-наукової освіти. Університетське ділове співробітництво як об'єкт аналізувалося у рамках сумісних 
практик, як приватних, так і суспільних (M. Ilyas, G. Dutrenit, D. Golder-Buckley, V. Garousi, K. Petersen). P. D'Este и M. Perkmann визначили фактори, які впливають на співробітництво між університетами i бізнесом, a також визначення типів співробітництва та переваг співробітництва (T. Davey, T. Baaken, V. Galan Muros, A. Meerman, T. Barnes, A. Gibbons, M. Crespo and H. Dridi) та визначити рівні співробітництва між університетами та діловим співробітництвом (B.N. Ponomariov, P.C. Boardman, T. Davey). Провідні вчені проаналізували співробітництво між університетом та бізнесом у покращенні змісту досліджень Т. Davey, A. Healy, C. Plewa, T. Baaken. Огляд вивчення цього об'єкта свідчить, що він був в основному проаналізований у професійній підготовці. Методологія дослідження. Окремі кількісні дослідження направлені на виявлення істотних форм університетського та ділового співробітництва та виявлення того, який бізнес приймає участь у розробці змісту дослідження (розробка, упровадження та оцінка). У дослідженні були застосовані наступні методи: аналіз наукової літератури, анкетування 3 дослідженням даних, які були оброблені математичним аналізом. Висновки.Результати опитування показали, що бізнес-організації приймають все більш активну участь в університетській діЯльсноті чеерз різні виді с півпраці, проте їх участь у розробці навчального співробітництва обмежується ще недостанім i обмеженим числом заходів. Представники бізнесу в основному приймають участь у розвитку лекцій у якості гостей та консультацій, які проводяться під час практики чи написання в підсумковому вигляді дипломної роботи, а також допомагають організувати заходи в університеті.

Ключові слова: університетське ділове співробітництво, форми співробітництва, розвиток навчального процесу, ділове співробітництво в дослідженні.

Ключевые слова: университетско-деловое сотрудничество, формы сотрудничества, развитие учебного процесса, содержание учебного процесса, деловое сотрудничество в исследовании.

МЕЙЕРИТЕ-НАРКЕВИЧЕНЕ КРИСТИНА - преподаватель кафедры менеджмента спорта, экономики и социологии Литовского университета спорта (Каунас, Литва).

E-mail: kristina.mejeryte@1su.lt, ORCID 0000-0003-0629-3265

\section{СОТРУДНИЧЕСТВО УНИВЕРСИТЕТА СО СТУДИЕЙ БИЗНЕСА И РАЗВИТИЯ}

Аннотация. Актуальность исследования отражает тот факт, что сотрудничество между университетом и бизнесом рассматривается как важный способ реализации третьей миссии университета. Университеты вынуждены искать новые возможности для финансирования, сокращения государственного финансирования и поддержки со стороны структурных фондов, а также быстрого роста деловой конкуренции, компании вынуждены искать новые методы для поддержания конкурентного преимущества. В обоих случаях различные формы сотрудничества являются важным способом достижения своих целей. Десять типов UBC напрямую связаны с миссиями университетов и бизнес-потребностями, но один из них очень важен - улучшение содержания исследования, которое анализируется с помощью разработки, внедрения и оценки содержания исследования. Такая форма сотрудничества между университетом и бизнесом может помочь в развитии человеческих ресурсов, связанных с развитием современного общества. Однако участие бизнеса в нем ограничено, а деятельность по привлечению внимания очень ограничена и не используется. Цель исследования определить формы деятельности, в которой участвуют представители бизнеса в целях улучшения содержания учебного процесса. Задачи исследования: определить формы сотрудничества между университетом, деловыми кругами и представителями бизнеса в области проектирования, внедрения и оценки содержания исследования. Анализ 
последних исследований и публикаций. С образованием третьей университетской миссии сотрудничество между университетами и бизнесом широко анализировалось не только в области управления, но и в области естественно-научного образования. Университетское деловое сотрудничество как объект анализировалось в рамках совместных практик, как частных, так и общественных (M. Ilyas, G. Dutrenit, D. GolderBuckley, V. Garousi, K. Petersen). P. D'Este и M. Perkmann определили факторы, влияющие на сотрудничество между университетами и бизнесом, а также определение типов сотрудничества, преимуществ сотрудничества (T. Davey, T. Baaken, V. Galan Muros, A. Meerman, T. Barnes, A. Gibbons, M. Crespo and H. Dridi) и определить уровни сотрудничества между университетами и деловым сотрудничеством (B.N. Ponomariov, P.C. Boardman, T. Davey). Основные ученые проанализировали сотрудничество между университетом и бизнесом в улучшении содержания исследований T. Davey, A. Healy, C. Plewa, T. Baaken. Обзор изучения этого объекта показывает, что он был в основном проанализирован в профессиональной подготовке. Методология исследования. Отдельные количественные исследования направлены на выявление существующих форм университетского и делового сотрудничества и определение того, какой бизнес участвует в разработке содержания исследования (разработка, внедрение и оценка). Для исследования были применены следующие методы: анализ научной литературы, анкетирование с исследованием данных, которые были обработаны математическим анализом. Выводы. Результаты опроса показали, что бизнес-организации все более активно участвуют в университетской деятельности через различные виды сотрудничества, но их участие в разработке учебного сотрудничества по-прежнему недостаточное и ограниченое небольшим числом мероприятий. Представители бизнеса в основном участвуют в развитии с гостевыми лекциями и консультациями, которые проводятся во время практики или написания окончательной (дипломной) работы, а также помогают организовать мероприятия в университете.

Ключевые слова: университетско-деловое сотрудничество, формы сотрудничества, развитие учебного процесса, содержание учебного процесса, деловое сотрудничество в исследовани.

Стаття рекомендована до публікащії д.філософ.н., проф. В.Г.Воронковою (Запоріжжя, Украӥна)

Надійшла до редколегіï: 23.09.2018 Прийнята до друку: 28.09.2018 